\title{
The Changing Role of Universities in Lithuanian Society
}

\author{
Saulius Spurga and Inga Žalènienè
}

The Lithuanian Republic was re-established on 11 March 1990 after the fall of the USSR, marking the beginning of a wave of reforms in the country's higher education (HE) sector. The prevailing assumption had been that, as a Soviet society, Lithuania enjoyed a high level of education at the tertiary level. Yet, the facts of the matter speak differently; during the Soviet period, only about $10 \%$ of the general population went on to obtain HE qualifications. Moreover, throughout the country, HE's development remained patchy. While it is fair to say that technical-related fields such as medicine and mathematics were sufficiently developed, the same could not be said for the social and humanitarian sciences, which had been under constant surveillance throughout the occupation. During the Cold War, the Communist authorities required these educational fields to serve the purposes of Soviet ideology and reinforce the merits of the regime, all of which had little or nothing to do with education.

In taking its first steps as an independent country, Lithuania faced many serious challenges. According to Claus Offe (Offe 1996: 34), the German political sociologist, the newly-independent states of Eastern Europe that emerged following the collapse of the USSR experienced transformation on three levels: nation-building; constitution-making; and the politics of allocation and distribution. Significantly, this needed to be achieved in a considerably short time frame and with limited experience. The field of education presented one of the greatest challenges. Insofar as high school education was concerned - formulated in the concept of a new Lithuanian education system drafted in 1992 - the task of middle schools was to cultivate independent and creative personalities. As for the universities, they were expected to play the vitally

S. Spurga $(\bowtie) \cdot$ I. Žalènienė

Mykolas Romeris University, Vilnius, Lithuania

e-mail: saspur@mruni.eu

I. Žalènienè

e-mail: izaleniene@mruni.eu

(C) The Author(s) 2021

H. van't Land et al. (eds.), The Promise of Higher Education,

https://doi.org/10.1007/978-3-030-67245-4_35 
important role of preparing specialists for a completely new economic system and a changing society.

In the first instance, newly trained specialists were needed in fields related to the social sciences, and to this end, several new universities with a primary focus on the social sciences were established soon after the formation of the Lithuanian state. The year 1990 saw the opening of the Police Academy of Lithuania (PAL), which in 1997 was renamed the Law Academy of Lithuania. In 2000, it became the Lithuanian University of Law, and in 2004 it received the name that it holds to this day - Mykolas Romeris University (MRU). The aforementioned university continues to educate and train specialists in fields that are crucial to the development of Lithuania's democracy, most notably, among others, matters of public security, public administration, law, and management.

In 2004, MRU became a member of IAU, which marked the start of an important journey towards intensive internationalisation of the university's studies and research. In 2008, the Rector of Mykolas Romeris University became one of the six European full Board Members of IAU. In 2010, Lithuania and MRU was chosen as a host country for an IAU International Conference "Ethics and Values in Higher Education in the Era of Globalisation: What Role for the Disciplines?", which was the unique opportunity to present Lithuania's Higher Education system to the world. It opened the doors for MRU to become part of global university networks and expand its international cooperation. In 2011, MRU carried out the comprehensive review of its internationalisation strategy ISAS coordinated by IAU. Following the recommendations of reputable international experts, MRU is continuing its vision to become a leading specialised social sciences university in Lithuania and in the region.

The early years following the reestablishment of the Republic of Lithuania has been referred to as the so-called "wild economy" stage, which was characterised by weak institutions, poor legal regulation and law enforcement that lacked the means to enforce. Yet, the country managed to get back on its feet, with young people acknowledging the value of higher education and even considering a university education. This coincided with a global trend of 'massification' in higher education which received a boost, particularly in Central and Eastern Europe, especially when compared to previous years when the level of education was considerably lower. The majority of the students were keen to choose social sciences.

Most of the country's universities were established by the Seimas - parliamentof the Republic of Lithuania, and are partially funded under the national budget. A few small universities function as for profit, limited liability companies.

In 2000, special secondary education institutions ("technical schools") were reorganised into colleges and granted the status of higher education institutions, providing ISCED Level 6 education. With colleges included in the system of higher education, the number of higher education institutions increased from 15 to 48 in a country with a population of just 3.5 million at that time. This also meant a sharp rise in the number of students at tertiary level. However, this reform is still considered to be controversial because it helped to promote the view that the oversupply of tertiary education resulted in a lower quality of education. 
In short, the state lacked the means to provide adequate funding for higher education, especially with the constant increase in student numbers. This problem was addressed in 2009 by the higher education reform introduced by a conservative, right-wing liberal government. It introduced a new funding model based on a 'student voucher', whereby the funding follows the student (European Commission 2011:48). The intention was to extend the student's choice of study programme, as well as to provide adequate funding. At the time, the mantra was that competition between universities would result in a greatly improved quality in HE.

Soon it became apparent that 'free choice' was failing to attract candidates to the study programmes and professions prioritised by the government. In modifying policy, the government dedicated a set number of vouchers for each of the academic fields. With the application of this model, competition between universities now takes place only in individual fields of study. Thus, a university funding system of this type prevails in Lithuania to this day. Whilst a great portion of students choose HE in the social sciences, the state prioritises the technological fields and other professions by granting more vouchers. For almost a decade, HE policy assumed that there was a surplus of social science professionals, but without any objective data being provided to justify this assertion.

During the global financial crisis (GFC) which seriously impacted the Baltic states from about the end of 2008 to 2010, many young people who had lost their jobs used this enforced free time to enrol at university. In 2010, more than 21,000 students were enrolled in Mykolas Romeris University. Meanwhile, politicians and even some education experts were quick to point out that in their view, HE massification resulted in the overall decline in quality and graduates struggling to find employment in their chosen field. There was, however, a more objective view underpinned by data which showed that most Lithuanians wanted to secure a tertiary qualification; indeed, such was the demand for skilled workers that wages were twice those of unskilled workers (European Commission 2011:10, 14). The importance of a higher education was further supported by observable trends during the crisis: unemployment rose sharply among low-skilled occupations, while skilled professionals more often managed to retain their jobs. Lithuania was and still remains a country where skilled professionals who obtain higher education have a significant advantage in comparison to less qualified workers (Oecd 2019:10,14).

Soon after the GFC crisis had passed, Lithuania's HE sector was faced with a decline in the number of students entering higher education, a trend common in many other EU countries. In the case of Lithuania, certain factors were also at work: the country was facing a serious demographic crisis due to declining birth rates and emigration. This was compounded by the government's declared goal of raising the quality of HE, which in practice meant restricting student access. Lithuania has a centralised system of final examinations of secondary education that ensures all school-leavers sit their examinations at the same time and are assessed according to the same criteria. The government has set a minimum score that must be reached during these exams in order to be eligible to enter higher education. A minimum score was also set for admission to state-funded places and is recommended for students who pay for their own studies. 
The decline in the number of HE students has been alarming. During the academic year 2008-2009, 210,400 students were enrolled in the country's HE institutions (Lietuvos 2016:11), with just 111,300 in the academic year 2018-2019 (Osp 2019). By this time, only 39\% of young people in the 20-24 age group were seeking higher education, compared to 2017 when $58 \%$ in the 30-34 age group had a tertiary qualification (Osp 2019). The outlook for the future looks bleak; as skilled workers retire, Lithuania will no longer be able to meet the demand for skilled labour in the near future.

It should also be noted that many graduates from schools with a lower quality of education have more difficulty in accessing higher education on account of changes to the national scoring system; such schools are generally attended by children from less affluent families.

At the dawn of independence in 1992, Lithuania's universities began their journey on the basis of academic freedom, yet over time they have been subject to the increasing pressure of state regulation, which has gone as far as violating the autonomy of universities. For example, a study on university autonomy conducted by the European University Association revealed that academic freedom in Lithuania's universities has been severely restricted. The 2016 academic autonomy ranking ranked the country $26^{\text {th }}$ among the EU's 28 analysed national higher education systems, although the organisational, financial and staffing autonomy of Lithuanian higher education was rated better (Eua 2020). Some decisions restricting the autonomy of universities were declared unconstitutional by the Lithuanian Constitutional Court. Worse still, the means of control seem to have no clear strategic objective(s) or framework, with measures and policies being frequently changed.

The position of the authorities would appear to be somewhat contradictory. While espousing "quality of education", they do not define the concept of quality which results in confused and conflicting policies. One case in point was the $2009 \mathrm{HE}$ reforms when the government proclaimed that competition would improve quality, although today they insist that competition is an example of inappropriate academic practice. On the one hand, massification is seen as a negative thing, but on the other hand, universities are constantly being redirected towards meeting the market demand. As in other countries, universities are constantly urged to justify the economic benefits of their research (which ignores the fact that the significance of research is often much broader and deeper) (Collini 2012) or to simply compete to achieve academic rankings, whose reliability is open to question. At the same time, state funding is very limited; Lithuania has one of the lowest levels of government spending per student at the tertiary level, which is twice as low as the OECD average (Oecd 2019). Such policies oblige universities to abandon their traditional mission, which only encourages influential (and poorly informed) political groups, who advocate for elite higher education, yet who refuse to take responsibility for the predicament in which universities find themselves.

Nevertheless, despite such problems and issues, Lithuanian universities are some of the most advanced institutions in the country, and continue to consolidate their reputations on the international stage, maintain high standards of transparency, continuously change and improve, as well as contribute significantly to the country's 
development. In 2018, the employment rate for tertiary-educated young adults in Lithuania was 93\%, which is higher than the OECD average (84\%) and the highest across OECD countries. The same can be said of wages, the pay gap between skilled and unskilled workers in Lithuania being the largest in the EU (Oecd 2019). Lithuania's growth in innovation is the highest in the European region and has reached about $20 \%$ over the last decade (Setkus 2020).

It is heartening to note that the attitude of the Lithuanian Government is starting to be more supportive, which may presage a shift in policy direction. State funding increased for undergraduate studies, especially by increasing the number of vouchers awarded in the field of social sciences and humanities, all of which is consistent with the needs of entrants. Furthermore, during the COVID-19 crisis, it became clear that Lithuanian universities were quickly adapting to the new conditions and moving smoothly to the remote mode.

\section{Conclusions}

In view of the aforementioned discussion, and the lessons learned from the recent COVID-19 crisis, a number of important issues need to be addressed if higher education is to continue to grow and contribute to the country's development. These include the need to:

- understand and evaluate the significance of HE in a broader sense: its impact reaches beyond a country's economic development and affects the society, national culture, quality of life in a broader sense;

- state focus on innovation and exchange of expertise, knowledge and research findings between HE institutions, businesses and other market participants;

- extend access to HE in particular, and recognise its substantial role in promoting wider inclusion by all groups in the community;

- increase investment by the state and HE institutions in creating virtual environments, platforms and open resources for studies and research. For this to happen, IT systems in HE institutions must be upgraded to apply to distance learning and blended studies, as well as the creation of effective IT support systems for students and lecturers;

- boost the digital competencies of lecturing staff, as well as empower them to organise a high-quality study process using modern advanced educational technologies;

- revise and quickly eliminate bureaucratic and legal obstacles that are holding back the further application of technology to study models in HE institutions;

- meet the challenge of decreasing the international mobility of students, which means ensuring "internationalisation at home" through the integration of virtual sessions of foreign teachers into national programmes, and distance learning facilities and opportunities for students living outside of Lithuania. 


\section{References}

Collini, S. (2012). What are universities for?. Penguin Books.

EUA. (n.d.). University Autonomy in Europe. Retrieved from: www.university-autonomy.eu/ (20.05.2020)

European Commission. (2011). Supporting growth and jobs - an agenda for the modernisation of Europe's higher education systems. Brussels: COM(2011) 567 final, 20. 9.2011.

Lietuvos Respublikos švietimo ir mokslo ministerija. Mokslo ir studiju stebėsenos ir analizès centras(2016) Lietuvos švietimas skaičiais 2016. Studjos. Vilnius.

OECD. (2019). Education At a Glance. Country Note. Lithuania. (pp.2). Retrieved from: www. oecd.org/education/education-at-a-glance/EAG2019_CN_LTU.pdf (20.05.2020)

Offe. C. (1996). Varieties of Transition: The East European and East German Experience. Cambridge: Polity Press.

Oficialiosios statistikos portalas (2019) Lietuvos švietimas, kultūra ir sportas. Aukštasis mokslas. Retrieved from: https://osp.stat.gov.lt/lietuvos-svietimas-kultura-ir-sportas/lietuvossvietimas-kultura-ir-sportas-2019/aukstasis-mokslas.\%20Accessed\%2020\%20May\%202020 (20.05.2020)

Šetkus, K. (2020). Kaip kuriame inovatyvia Lietuva ir kokie iššukiai laukia ateityje. Verslo žinios, March 19, Retrieved from: www.vz.lt (20.05.2020)

Saulius Spurga is the Deputy Rector of Mykolas Romeris University. He also lectures at the University and undertakes the duties of an Associate Professor. He has been elected to Mykolas Romeris University's Senate and is now the Senate Secretary. He regularly publishes articles, reviews and analysis of Lithuanian society and political life in various types of mass media.

Inga Žalėnienė was appointed as Vice-Rector for Research and International Relations in 2012, then in 2017 as Vice-Rector for Education and Research and since March 2019, she holds the position of Rector of Mykolas Romeris University. Inga Žalènienè is an IAU Board member since 2017.

Open Access This chapter is licensed under the terms of the Creative Commons Attribution 4.0 International License (http://creativecommons.org/licenses/by/4.0/), which permits use, sharing, adaptation, distribution and reproduction in any medium or format, as long as you give appropriate credit to the original author(s) and the source, provide a link to the Creative Commons license and indicate if changes were made.

The images or other third party material in this chapter are included in the chapter's Creative Commons license, unless indicated otherwise in a credit line to the material. If material is not included in the chapter's Creative Commons license and your intended use is not permitted by statutory regulation or exceeds the permitted use, you will need to obtain permission directly from the copyright holder. 